\title{
PELAKSANAAN PEMBERI BANTUAN HUKUM DIKAITKAN DENGAN UNDANG-UNDANG NO. 16 TAHUN 2011 TENTANG BANTUAN HUKUM
}

\author{
Iwan Wahyu Pujiarto \\ Syafruddin Kalo, Eka Putra, Edy Ikhsan
}

\author{
Universitas Sumatera Utara \\ J1. Dr. T. Mansyur No. 9, Medan, Sumatera Utara 20155 \\ Email: iwan.wahyu3@gmail.com
}

\begin{abstract}
Legal aid is present to provide protection against any person or group of poor people. State through the Ministry of Justice and Human Rights as Legal Aid organizers should be able to deliver justice in the legal field to the poor either not problematic or problematic law. Mencoboba researchers focus on implementation issues legal aid aims to determine the setting of legal aid in Indonesia, to determine the legal position in the implementation of the legal aid Act No. 16 Year 2011 regarding Legal Aid, and to determine the factors that affect the implementation of Legal Aid. Researchers try to find the problem regarding the setting and the factors that affect the implementation of legal aid, to address these problems used normative juridical research methods, analytical descriptive, using the theory of justice, the data used secondary data from the literature, with the approach of legislation.

Based on the results of the study, Indonesia has attempted to provide protection against any person or group of poor people who lodged lawsuits with the enactment of the Legal Aid Act, Regulation of the Minister of Law and Human Rights No. 3 Year 2013 regarding Procedures for Verification and Accreditation of Legal Aid or social organizations provide legal assistance to persons or groups of poor people, the Indonesian Government Regulation No. 42 Year 2013 regarding Terms and Procedures for Granting Legal Aid and Legal Aid Disbursement, Regulation of the Minister of Justice and Human Rights of the Republic of Indonesia Number 22 Year 2013 About the Implementation Regulation Government Regulation No. 42 Year 2013 About Terms and Procedures for Granting Legal Aid and Legal Aid Disbursement. Results of this study concluded that the provision of legal assistance to the poor as regulated in Act Number 16 Year 2011 concerning the Legal Aid does not run according to the rules, terms as Managing Aid Legal impede the provision of legal aid, legal aid does not run as expected because it is still affected by the lack of proper implementation of the rules.
\end{abstract}

Key words: implementation, legal aid providers, Act Number 16 Year 2011 Regarding Legal Aid

\section{Akbstrak}

Bantuan Hukum hadir untuk memberikan perlindungan terhadap orang atau kelompok orang miskin. Negara melalui Kementerian Hukum dan Hak Asasi Manusia sebagai Penyelenggara Bantuan Hukum harus dapat memberikan keadilan di bidang hukum kepada golongan miskin baik yang tidak bermasalah maupun yang bermasalah hukum. Peneliti mencoboba fokus terhadap masalah pelaksanaan pemberi bantuan hukum bertujuan untuk mengetahui pengaturan 
bantuan hukum di Indonesia, untuk mengetahui kedudukan hukum Pemberi Bantuan Hukum dalam pelaksanaan Undang-Undang No. 16 Tahun 2011 Tentang Bantuan Hukum, dan untuk mengetahui faktor-faktor yang mempengaruhi implementasi Pemberi Bantuan Hukum.

Peneliti mencoba menemukan masalah mengenai pengaturan dan faktor yang mempengaruhi pelaksanaan pemberi bantuan hukum, untuk menjawab permasalahan tersebut digunakan metode penelitian yuridis normatif, bersifat deskriptif analitis, menggunakan teori keadilan, data yang digunakan data sekunder dari studi pustaka, dengan pendekatan perundang-undangan. Berdasarkan hasil penelitian, Indonesia telah berupaya memberikan perlindungan terhadap orang atau kelompok orang miskin yang tersangkut perkara hukum dengan diundangkannya UndangUndang Bantuan Hukum, Peraturan Menteri Hukum dan Ham No. 3 Tahun 2013 Tentang Tata Cara Verifikasi dan Akreditasi Lembaga Bantuan Hukum atau Organisasi Kemasyarakatan yang memberikan bantuan hukum kepada orang atau kelompok orang miskin, Peraturan Pemerintah Republik Indonesia Nomor 42 Tahun 2013 Tentang Syarat dan Tata Cara Pemberian Bantuan Hukum dan Penyaluran Dana Bantuan Hukum, Peraturan Menteri Hukum dan Hak Asasi Manusia Republik Indonesia Nomor 22 Tahun 2013 Tentang Peraturan Pelaksanaan Peraturan Pemerintah Nomor 42 Tahun 2013 Tentang Syarat dan Tata Cara Pemberian Bantuan Hukum dan Penyaluran Dana Bantuan Hukum. Hasil penelitian ini menyimpulkan bahwa pemberian bantuan hukum kepada orang miskin yang diatur dalam Undang-Undang Nomor 16 Tahun 2011 Tentang Bantuan Hukum tidak berjalan sesuai aturan, syarat sebagai Pelaksana Pemberi Bantuan Hukum menghambat pemberian bantuan hukum, pemberian bantuan hukum tidak berjalan sesuai harapan karena masih dipengaruhi oleh aturan pelaksanaan yang kurang tepat.

Kata kunci: pelaksanaan, pemberi bantuan hukum, Undang-undang Nomor 16 Tahun 2011 tentang Bantuan Hukum

\section{Latar Belakang}

Perubahan besar terjadi dalam penyelenggaraan negara di bidang bantuan hukum, namun sulit untuk menyajikan suatu sistem perundang-undangan bidang bantuan hukum secara tepat guna, hal tersebut karena terdapat beberapa peraturan yang mengatur tentang bantuan hukum, selain itu tidak semua kondisi telah diatur dalam peraturan perundangan yang bersifat teknis sebagaimana telah diatur dalam Undang-Undang Nomor 16 Tahun 2011 Tentang Bantuan Hukum selanjutnya dalam naskah ini disingkat UUBH beserta turunannya. ${ }^{1}$

Bantuan hukum (legal aid) adalah jasa memberi nasehat hukum kepada orang yang tidak mampu, miskin (penghasilan rendah) dan buta hukum (buta huruf atau berpendidikan rendah, tidak berani memperjuangkan hak-haknya akibat tekanan dari yang lebih kuat) untuk mendapatkan perwakilan hukum dan akses di pengadilan baik nonlitigasi maupun litigasi secara adil tanpa adanya diskriminasi. ${ }^{2}$ Dasar pertimbangan Bantuan Hukum adalah Undang-Undang Dasar 1945 selanjutnya disingkat UUD’45 pada Pasal 27 ayat (1), fakir miskin memiliki hak konstitusi untuk diwakili dan dibela oleh negara melalui Advokat atau pembela umum (legal service). ${ }^{3}$ Jaminan setiap orang untuk mendapat perlakuan yang sama di hadapan hukum sebagai pencerminan asas equality protection

1 Frans Hendra Winarta, Pro Bono Publico: Hak Konstitusional Fakir Miskin untuk Memperoleh Bantuan Hukum, Gramedia, Jakarta, 2009, hlm. 2. 
the law dan asas equal justice under the law yang dijamin dalam UUD'45 Pasal 28d ayat $(1),{ }^{4}$ hal ini sebagaimana telah di isyaratkan dalam UUBH Pasal 12 memuat Penerima Bantuan Hukum berhak mendapatkan bantuan hukum.

Pasal 28h ayat (2) UUD'45 menyatakan bahwa tiap orang berhak mendapat kemudahan dan perlakuan khusus untuk memperoleh kesempatan dan manfaat yang sama guna mencapai persamaan dan keadilan yang dalam UUBH tersirat dalam aturan tentang permohonan Penerima Bantuan Hukum pada ketentuan Bab VI Pasal 14 sampai 15 UUBH dipermudah dalam aturan khusus pada Pasal 7 ayat (2), Pasal 8 sampai Pasal 10 Peraturan Pemerintah No. 42 Tahun 2013 terhadap pemohon yang tidak dapat tulis baca dan tidak memiliki identitas kependudukan.

Ketentuan Undang-Undang No. 39 Tahun 1999 Tentang HAM khususnya pada Pasal 4 menjadi ketentuan yang berpengaruh besar terhadap lahirnya UUBH yang merupakan upaya pemenuhan tanggung jawab negara dalam memberikan perlindungan kepada warganya, dimana menyebutkan adanya pengakuan hak untuk hidup, tidak disiksa, kebebasan pribadi, pikiran dan hati nurani, beragama, tidak diperbudak, diakui sebagai pribadi dan persamaan dihadapan hukum, dan untuk tidak dituntut atas dasar hukum yang berlaku surut adalah hak asasi manusia yang tidak dapat dikurangi dalam keadaan apapun dan oleh siapapun yang juga dimuat pada UUD'45 Pasal 28i ayat (1). ${ }^{5}$ Pasal 28i ayat (4) UUD'45 menyatakan perlindungan, pemajuan, penegakan, dan pemenuhan hak asasi manusia adalah tanggung jawab negara, terutama pemerintah, dimana melalui UUBH pemerintah menjamin perlindungan hukum masyarakat miskin dan buta hukum. Pasal 28i ayat (5) UUD'45 dalam menjamin perlindungan hak asasi manusia mengenai bantuan hukum sebagaimana pada Bab III Pasal 6 sampai Pasal 7 menyatakan bantuan hukum diselenggarakan oleh Menkumham melalui BPHN dan Kemenkumham yang dipertanggung jawabkan ke DPR.

Negara mengakui adanya hak-hak dalam ekonomi, sosial, budaya, sipil dan politik bagi para fakir miskin, maka secara konstitusional orang miskin berhak untuk diwakili dan dibela baik didalam maupun diluar pengadilan (acces to legal counsel). Bantuan hukum bagi si miskin termuat dalam Pasal 34 ayat (1) UUD'45. Jadi bantuan hukum adalah hak dari orang yang tidak mampu yang dapat diperoleh tanpa bayar (pro bono publico) sebagai penjabaran persamaan hak di hadapan hukum. ${ }^{6}$ Pasal 34 ayat (2) dan ayat

2 Ibid.

3 Syafruddin Kalo, Kuliah Hukum Pidana Pascasarjana USU, Rabu, 23 Oktober 2013.

4 Frans Hendra Winarta, Bantuan Hukum: Suatu Hak Asasi Manusia Bukan Belas Kasihan, Elex Media Komputindo, Jakarta, 2000, hlm. 29.

5 Ibid.

6 Syafruddin Kalo, Op.cit. 
(4) UUD'45 bahwa negara mengembangkan sistem jaminan sosial bagi seluruh rakyat dan memberdayakan masyarakat yang lemah dan tidak mampu sesuai dengan martabat kemanusiaan yang diatur dalam UUBH.

Pada UUBH Pasal 22 ayat (1) UndangUndang No. 18 Tahun 2003 dan Kode Etik PERADI Pasal 7 point $\mathrm{h}$ telah diatur bahwa Advokat wajib memberikan bantuan hukum secara cuma-cuma (pro deo) kepada pencari keadilan yang tidak mampu. Isu hukum lain disebagian kalangan Advokat terhadap eksistensi LBH dan Orkemas yang memenuhi standar Pelaksana Pemberi Bantuan Hukum dapat merekrut paralegal, dosen, mahasiswa FH dalam memberikan nasihat atau Bantuan Hukum kepada masyarakat secara litigasi maupun non-litigasi yang diakui dalam ketentuan UUBH Pasal 4 ayat (3).

UUBH Pasal 5 menyebutkan hanya orang miskin yang tidak dapat memenuhi hak dasar secara layak dan mandiri saja, maka bagaimanakah perlindungan hukum pada orang atau kelompok marjinal (perempuan, anak, buruh, petani, korban pencemaran lingkungan,dll) karena kebijakan publik, selain itu terdapat pula orang yang hak sipil dan politiknya terabaikan, masyarakat adat yang buta hukum, orang atau kelompok imigran yang juga perlu dilindungi hak-haknya, dan bagaimana terdakwa dengan ancaman pidana 15 tahun atau lebih dan hukuman mati atau bagi mereka yang tidak mampu yang diancam pidana 5 tahun atau lebih.
Jurnal ini akan membahas tentang pelaksanaan pemberian bantuan hukum yang dilihat dari peraturan yang diberlakukan (bantuan hukum proses pidana), para Pemberi Bantuan Hukum, sampai pada faktor-faktor yang berpengaruh terhadap pelaksanaan pemberian bantuan hukum.

Berdasarkan permasalahan diatas, maka diajukan suatu jurnal dalam bentuk Tesis dengan judul "Pelaksanaan Pemberi Bantuan Hukum Dikaitkan Dengan Undang-Undang No. 16 Tahun 2011 Tentang Bantuan Hukum”.

Berdasarkan latar belakang yang telah dijelaskan maka pokok permasalahan dalam jurnalan ini adalah Bagaimanakah pengaturan bantuan hukum di Indonesia? Bagaimanakah kedudukan hukum Pemberi Bantuan Hukum dalam pelaksanaan Undang-Undang No. 16 Tahun 2011 Tentang Bantuan Hukum? Apa faktor-faktor yang mempengaruhi implementasi Pemberi Bantuan Hukum? Permasalahan tersebut bertujuan untuk mengetahui pengaturan bantuan hukum di Indonesia, untuk mengetahui kedudukan hukum Pemberi Bantuan Hukum dalam pelaksanaan Undang-Undang No. 16 Tahun 2011 Tentang Bantuan Hukum, dan untuk mengetahui faktor-faktor yang mempengaruhi implementasi Pemberi Bantuan Hukum.

Manfaat yang diharapkan dari jurnal ini adalah hasil jurnal ini diharapkan dapat berguna dalam memberikan tambahan pemikiran dan masukan bagi pemerintah untuk menyempurnakan dan menyusun lebih 
lanjut tentang kebijakan-kebijakan di bidang hukum, khususnya yang terkait dengan bantuan hukum di Indonesia.

Hukum harus menjamin bahwa setiap orang dengan kedudukannya dimuka hukum dan pengadilan tidak membedakan strata sosial dalam mendapat keadilan. Terhadap hal ini maka disahkannya Undang-Undang No. 16 Tahun 2011 Tentang Bantuan Hukum yang diharapkan agar lebih konsisten dalam melindungi hak-hak setiap orang yang tidak mampu. ${ }^{7}$

Teori yang digunakan dalam jurnal ini adalah teori keadilan, adalah kebajikan utama dalam institusi sosial, sebagaimana kebenaran dalam sistem pemikiran. Tidak semua posisi sosial adalah relevan, sebisa mungkin keadilan sebagai fairness. ${ }^{8}$ Keadilan disini dalam hal hak dan kewajiban sama dihadapan hukum tanpa melihat status sosial dan kekayaan. ${ }^{9}$

Plato di dalam Mohammad Muslehuddin menyebutkan tentang keadilan: ${ }^{10}$

"in his view, justice consist in a harmonious relation, between the various parts of the social organism. every citizen must do his duty in his a haunted place and do the thing for which his nature is best suited."

Plato dalam mengartikan keadilan dipengaruhi cita-cita kolektivistik yang memandang keadilan terdiri dari hubungan yang harmonis, antara organisme sosial. Setiap warga negara harus melakukan tugas sesuai dengan posisi dan sifat alamiahnya. Pembuat peraturan harus menempatkan dengan jelas posisi setiap kelompok masyarakat dimana dan situasi bagaimana yang cocok untuk seseorang. Hal ini karena setiap orang bukanlah suatu jiwa yang terisolir dan bebas melakukan apa saja yang dikehendakinya dengan tetap pada aturan dan tatanan universal yang menundukkan keinginan pribadinya sebagai makhluk sosial.

Aristoteles berpandangan keadilan berisi suatu unsur kesamaan, semua benda yang ada di alam ini dibagi secara rata dimana pelaksanaannya dikontrol oleh hukum. Keadilan dibagi menjadi keadilan distributif dan keadilan korektif. Keadilan distributif adalah keadilan yang ditentukan oleh pembuat undang-undang, distribusinya memuat jasa, hak dan kebaikan bagi anggota-anggota masyarakat menurut prinsip kesamaan proporsional. Sedangkan keadilan korektif adalah keadilan yang menjamin, mengawasi dan memelihara distribusi ini melawan serangan-serangan ilegal. Fungsi korektif keadilan pada prinsipnya diatur oleh hakim dan menstabilkan kembali status quo dengan cara mengembalikan milik korban yang bersangkutan atau dengan cara mengganti rugi atas miliknya yang hilang. ${ }^{11}$

7 Abdurrahman Riduan Syahrani, Hukum dan Peradilan, Alumni, Bandung, 1978, hlm. 71.

8 John Rawls, A Theory of Justice: Teori Keadilan, Pustaka Pelajar, Yogyakarta, 2006, hlm. 133-134.

9 Ibid., hlm. 114-118.

10 Mohammad Moslehudin, Philosophy of Islamic Law And The Orientalists: A Comparative Study of Islamic Legal System, Islamic Publications, Lahore, 1986, hlm. 42.

11 Mohammad Moslehudin, Filsafat Hukum Islam dan Pemikiran Orientalis: Studi Perbandingan Sistem Hukum Islam, Tiara Wacana Yogya, Yogyakarta, 1991, hlm. 36. 
Aristoteles mempengaruhi pandangan John Rawls, dimana subjek utama keadilan adalah struktur dasar masyarakat, atau lebih tepatnya cara lembaga-lembaga sosial utama mendistribusikan hak dan kewajiban fundamental serta menentukan pembagian keuntungan dari kerja sama sosial. ${ }^{12}$

Berdasarkan hal tersebut, pandangan teori keadilan membantu dalam menggambarkan unsur konstitutif sistem hukum yang diberlakukan negara dan tujuan dari kebijakan pemerintah terkait dengan bantuan hukum yang diperuntukkan kepada setiap orang atau kelompok orang miskin.

\section{Pembahasan}

\section{A. Pengaturan Bantuan Hukum}

Bantuan hukum menurut Mauro Cappelletti sebenarnya telah dilaksanakan pada masyarakat barat sejak jaman romawi, dimana saat itu bantuan hukum berada dalam bidang moral. ${ }^{13}$ Setelah meletusnya Revolusi Perancis, bantuan hukum kemudian mulai menjadi bagian dari kegiatan hukum atau kegiatan yuridik, dengan mulai lebih menekankan pada hak yang sama bagi warga masyarakat untuk mempertahankan kepentingan-kepentingannya di muka pengadilan, dan hingga awal abad ke-20 bantuan hukum ini lebih dianggap sebagai pekerjaan memberi jasa di bidang hukum tanpa suatu imbalan. ${ }^{14}$

Sejarah awal bantuan hukum di Indonesia dimulai ketika di Belanda terjadi perubahan besar dalam sejarah hukumnya. Berdasar asas konkordansi dimana peraturan Firman Raja 16 Mei 1848 No. 1 juga diberlakukan di Indonesia, antara lain susunan Kehakiman dan Kebijaksanaan Pengadilan (Reglement op de Rechterlijke Organisatie en het beleid der Justitie) atau $\mathrm{RO}^{15}$ dimana terdapat aturan mengenai Advokat dan Pengacara dalam BAB VI memuat Advokat merangkap sebagai pengacara, saat itu Advokat hanya memberikan jasanya dalam proses perdata dan pidana, ini juga mengatur lebih rinci mengenai jarak tempat tinggal Advokat antara 3 sampai 5 paal $^{16}$ dari tempat menjalankan prakteknya atau pengadilan tempat Advokat tersebut bersidang.

Seseorang yang dapat diangkat menjadi Advokat adalah mereka yang berkaula negara Belanda dan mempunyai ijazah Universitas di negeri Belanda atau ijazah Rechts Hogeschool (RHS) di Jakarta, biasanya Advokat di

12 John Rawls, Op.cit., hlm. 7-8.

13 Sr. Mauro Cappelletti, Earl Johnson Jr. Dan James Gord Ley, Towards Equal Justice, A Comparative Study of Legal Aid in Modern Societies, Dobbes Ferry, New York, 1976, hlm. 6.

14 Bambang Sunggono dan Aries Harianto, Bantuan Hukum dan Hak Asasi Manusia, Mandar Maju, Bandung, 2009, hlm. 11.

15 Jhony Ibrahim, Teori dan Metodologi Jurnal Hukum Normatif, Bayumedia Publishing, Surabaya, 2005, hlm. 132.

16 Paal adalah satuan ukuran jarak dimana 1 paal di jawa sama dengan 1.507 meter sedangkan 1 paal di sumatera sama dengan 1.852 meter, adapun perbedaan ukuran di jawa dan sumatera terkait dengan permainan jual-beli tanah perkebunan oleh VOC. 
Indonesia masa pendudukan Belanda adalah mereka yang telah bergelar Doktor Ilmu Hukum dan Meester in de Rechten.

Peraturan Bantuan Hukum terdapat dalam RO Pasal 190 memuat para Advokat dan procurer bila ditunjuk oleh badan pengadilan, wajib memberikan bantuan hukum secara cuma-cuma atau separuh dari tarif biaya yang berlaku. ${ }^{17}$

Landasan yuridis bantuan hukum saat kemerdekaan Herziene Inlandsch Reglement (HIR) Pasal 250 dimana pemberian bantuan hukum untuk terdakwa yang diancam hukuman mati atau hukuman seumur hidup. Kemudian diundangkan Undang-Undang No. 14 Tahun 1970 yang mengatur ketentuan pokok Kekuasaan Kehakiman, dan tambahan Lembaran Negara No. 2951.

Point utama yang terkait dengan Bantuan Hukum masa pendudukan Belanda terdapat dalam Reglement op de Rechterlijke Organisatie en het beleid der Justitie Pasal 190 memuat: ${ }^{18}$

"De Advocaten en procureurs, daartoe door de regterlijke collegien, voor welke zij hunne bediening uitoefenen aangewezen, zijn verplight om gratis den wel tegen half salaris hunnen bijstand te veerlenen aan hen, die verguning hebben bekomen onderscheidenlijk om kosteloos, den wel tegen verminderd tarief te procedeeren.
Zij zijn mede gehouden om zijk gratis te belasten met de verdediging in strafzalken, wanneer hun dit door den regter wordt op ged ragen zij kunnen zich aan die verpligtingen niet onttrekken, dan om redenen door den president van het betrokkene colligie goedge keurd."

Terjemahan, paraAdvokat dan procurerbila ditunjuk oleh badan pengadilan, dimana ia diangkat, wajib memberikan bantuan hukum secara cuma-cuma atau separuh dari tarif biaya yangberlaku, guna menolong mereka yang telah mendapatkan ijin berproses tanpa biaya atau di bawah tarif yang berlaku.

Advokat dalam menjalankan tugasnya diawasi oleh Majelis Hakim (Majelis Hakim ditambah dua orang Advokat). apabila Advokat melakukan perbuatan-perbuatan yang bertentangan dengan kewajiban dan kehormatannya selaku Advokat dan pengacara ataujuga apabila mereka ini menunjukkan sikap tidak hormat terhadap majelis hakim atau para anggotanya atau pejabat pengadilan lainnya, dan juga termasuk dalam menggunakan kata-kata yang tidak pada tempatnya terhadap Undang-Undang atau kekuasaan umum dan juga menurut keadaan, sanksi yang dapat diberikan oleh Majelis Hakim berupa pemecatan sementara (schorsing) untuk jangka waktu setinggi-tingginya enam bulan atau dikenakan denda paling tinggi $\mathrm{f}$. $200,-{ }^{19}$ untuk kepentingan orang-orang yang

17 Abdurrahman, Op.cit., hlm. 41-42.

18 Abdurrahman, Op.cit., hlm. 41-42.

$19 \mathrm{~F}$ atau fl (Florijn atau Florin) adalah mata uang Belanda sejak abad ke-17 hingga 2002 yang kini digantikan dengan Euro. Satu Florijn sama dengan 2.20371 Gulden/Guilder Belanda (NLG) atau sama dengan 0.9999995238 Euro ( 1 Gulden=0.453780 Euro) atau setara dengan Rp.15060.084518384 (1Euro=15060.09169 IDR). Pada masa Vereenigde Oostindische Compagnie (VOC) tahun 1833, 1 Gulden setara 120 sen, dan pada 18541 Gulden setara 100 sen. 
tidak mampu, dengan memerintahkan pula untuk membayar ganti rugi seluruhnya atau sebagian yang ditimbulkan oleh kesalahannya atau kelalaiannya dalam memperhatikan para pihak yang berperkara. Sebagaimana Advokat yang menerima teguran oleh Majelis Hakim dapat mengajukan banding dengan surat permohonan dalam waktu empat belas hari setelah hari keputusan telah diucapkan kepada Hooggerechtshof atau Hof atau disingkat H.g.H. dan apabila tingkah laku negatif Advokat tesebut diulangi kembali atau terjadi kelampauan batas yang tidak semestinya maka H.g.H karena jabatannya atau berdasarkan usul dari Raden van Justitie atau disingkat sebagai R.v.J. (Pengadilan Tinggi) dapat mengusulkan kepada Gouvenieur Generaal atau disingkat G.G. (Menteri Kehakiman).

Landgerech yang dibentuk pada 1914 secara umum dapat memproses semua golongan jika terjadi perkara hukum meskipun pengadilan ini hanya memeriksa pelanggaran pidana ringan saja dimana orang Belanda juga sebagai hakimnya. Pelaksanaan Bantuan Hukum yang diberlakukan menurut asas konkordansi tersebut hanya sekedar peraturan di Hindia, peraturan Bantuan Hukum tersebut hanya berlaku untuk golongan Eropah.

Adanya ketidakadilan semakin dirasakan oleh penduduk asli Indonesia dengan adanya pengelompokan golongan-golongan masyarakat sebagaimana diatur dalam
Indische Staatsregeling atau disingkat IS (Peraturan Ketatanegaraan Hindia Belanda) yang mulai diberlakukan tahun 1926 dimana pada Pasal 163 ayat (1) memuat:

\section{a. Eropah}

Yang termasuk golongan Eropah adalah orang Belanda, dan semua orang bukan Belanda yang asalnya dari Eropah, orang Jepang (berdasarkan perjanjian Nedherland dan Japan dalam Lapangan Perdagangan dan Perkapalan), orang-orang yang tidak termasuk orang Belanda atau Eropah lainnya, akan tetapi taat pada Hukum Keluarga yang pada garis besarnya sama dengan asas-asas hukum keluarga yang terdapat dalam BW/KUHS ( orang Amerika, Canada, Afrika Selatan, dan Australia, dan juga orang yang secara sah merupakan keturunan Belanda), dan orang yang tidak berasal dari Belanda tetapi di negaranya menganut hukum kekeluargaan yang sifat dan coraknya sama dengan Belanda.

Dalam perkembangannya muncul istilah Gelijkstelling $^{20}$ diatur dalam Pasal 109 RR baru (amandemen Pasal 109 ayat 5 RR lama) yang akhirnya menjadi Pasal 163 IS yang menyatakan lembaga Gelijkstelling diganti dengan Toepasselijkverklaring van de Bepalingen Europeanen. ${ }^{21}$ Pasal 109 RR baru mengatur bahwa orang Timur Asing dan orang Pribumi dapat dipersamakan dengan orang Eropah atas permintaannya sendiri. Ketentuan mengenai Gelijkstelling ini ditentukan

20 Gelijkstelling adalah pembauran, dipersamakan menurut hukum, persamaan yang diberikan kepada Pribumi atau orang Timur Asing yang dengan syarat tertentu mendapat hak-hak yang sama seperti orang Eropa.

21 Toepasselijkverklaring van de Bepalingen Europeanen merupakan memperlakukan ketentuan hak orang Eropah terhadap orang Indonesia dan Timur Asing. 
dengan ordonasi dan kemudian dimuat dalam

Staatblad. Orang yang dipersamakan menurut staatblad ini dikenal dengan istilah orang Eropah Staatsblad (Staatsblad Europeanen).22 Gelijkstelling dapat dilakukan oleh orang Timur Asing dan orang Pribumi dengan memenuhi syarat-syarat tertentu, yaitu:

1) Sebelum tahun 1894 :

a. Beragama kristen,

b. Fasih bercakap dan menulis dalam bahasa Belanda.

c. Berpendidikan dan beradat-istiadat Belanda.

d. Mempunyai kecakapan penuh (volkman geschiktheid) untuk bergaul dengan masyarakat Eropah.

2) Tahun 1894, Syarat-syarat yang tersebut diatas dirubah menjadi mempunyai kecakapan untuk bergaul dengan masyarakat Eropah, sedangkan agama yang dianut tidak lagi menjadi batasan atau dihilangkan.

3) Tahun 1913, syarat yang lebih diutamakan untuk mempermudah orang menjadi Gelijkstelling adalah kebutuhan hukum dari yang bersangkutan, dimana dengan tujuan bahwa orang tersebut bersedia tunduk dan menerima Personenrecht ${ }^{23}$ dan Familierecht European ${ }^{24}$.
Personenrecht dan Familierecht atau tentang orang (van personen) diatur dalam Burgelijk Wetboek pada Buku I dimana menjelaskan hukum perorangan dan hukum keluarga yaitu hukum yang mengatur status serta hak dan kewajiban yang dimiliki oleh subjek hukum, antara lain mengenai ketentuan timbulnya hak keperdataan seseorang, kelahiran, kedewasaan, perkawinan, keluarga, perceraian dan hilangnya keperdataan.

b. Bumi Putera

Yang termasuk golongan Bumi Putera adalah semua orang asli dari Indonesia.

c. Timur Asing

Yang termasuk golongan Timur Asing adalah semua orang yang bukan orang Eropah dan / atau bukan orang Bumi Putera (Tionghoa, Arab, India, Pakistan, dan sebagainya).

Bantuan hukum pada masa penjajahan Jepang menggunakan Burgerlijk Wetboek (BW) atau Kitab Undang-Undang Hukum Perdata dan Wetboek van Koophandel (WvK) atau kitab hukum dagang, sedangkan untuk golongan asli Indonesia menggunakan hukum adat. Wetboek van Strafrecht (WvS) atau Kitab Undang-Undang Hukum Pidana dari masa penjajahan Belanda masih diberlakukan selain peraturan-peraturan pidana lainnya

22 Asis Safioedin, Beberapa Hal Tentang Burgerlyk Wetboek, Alumni, Bandung, 1973, hlm. 38.

23 Personenrecht atau hukum perorangan atau hukum pribadi. Personenrecht adalah semua kaidah hukum yang mengatur mengenai siapa saja yang dapat membawa hak dan kedudukannya dalam hukum. Hukum perorangan terdiri dari: peraturan-peraturan manusia sebagai subjek hukum, kewenangan hukum, domestik dan catatansipil. Peraturan-peraturan tentang kecakapan untuk memiliki hak-hak dan untuk bertindak sendiri melaksanakan hak-haknya tersebut.

24 Familierecht atau hukum keluarga adalah semua kaidah hukum yang mengatur hubungan abadi antara dua orang yang berlainan jenis kelamin dan akibatnya hukum keluarga sendiri dari: perkawinan beserta hubungan dalam hukum harta kekayaan antara suami/istri, hubungan antara orang tua dan anak-anaknya, perwalian, pengampuan. 
yang dibuat penjajah Jepang yang diantaranya adalah Osamu Gunrei Nomor 1 Tahun 1942 pada Pasal 3 yang dikeluarkan oleh Pembesar Bala Tentara Dai Nippon untuk Jawa dan Madura (mengenai hal ini boleh dikatakan sama saja untuk daerah luar Jawa dan Madura) yang memuat antara lain: ${ }^{25}$

"Semua badan-badan pemerintahan dan kekuasaannya, hukum dan Undang-Undang dari pemerintah yang dulu, tetap diakui untuk sementara waktu, asal saja tidak bertentangan dengan aturan Pemerintah Militer."

Kemudian Undang-Undang Nomor Istimewa Tahun 1942 yang termasuk didalamnya memuat Osamu Gunrei Nomor 25 Tahun 1944 Tentang Gunsei Keizirei (UndangUndang Kriminal Pemerintah Balatentara), Pada Pasal 47 Gunzei Keizirei kekuatan Undang-Undang ini berlaku surut, yang diatur dalam aturan umumnya adalah jenisjenis pidana yang berbentuk kesengajaan, percobaan, konkursus, penyertaan, dan rechterlijk pardon ${ }^{26}$. Osamu Seirei Nomor 24 Tahun 1944 tentang mengadili orang-orang Jepang (Nippon) baik dalam perkara perdata maupun pidana.

Pada intinya bahwa perubahan-perubahan yang dilakukan dalam periode pendudukan Jepang dilakukan dengan mengganti warna Belanda dengan warna Jepang, sembari disisi lain, menghilangkan hak-hak istimewa orang Belanda dan Eropah lainnya, UndangUndang pendudukan Belanda masih dapat diberlakukan asalkan tidak bertentangan dengan militer Jepang. Pembaharuan yang dilakukan masa pendudukan Jepang di bidang peradilan di Indonesia antara lain: ${ }^{27}$

a. Penghapusan dualisme atau pluralisme tata peradilan, sehingga hanya ada satu sistem saja untuk semua golongan penduduk (kecuali untuk orang Jepang, karena orang Jepang di Indonesia menggunakan aturan Jepang). Semua badan pengadilan (kecuali Residentiegerecht, yang khususnya untuk orang Belanda dan Eropah), dengan nama yang diganti dengan istilah Jepang;

b. Unifikasi kejaksaan, fungsi officieren van justitie (yang bekerja dibawah arahan hukum acara pidana untuk orang-orang Eropah) disatukan dengan fungsi jaksa untuk orang-orang pribumi ke dalam Kensatzu Kyoku, yang diorganisasi menurut tiga tingkat peradilan;

c. Penghapusan pembedaan polisi kota dan polisi pedesaan/lapangan;

d. Pembentukan lembaga pendidikan hukum, khususnya untuk menghasilkan hakim dan jaksa;

e. Pengisian secara serentak jabatan-jabatan administrasi pemerintahan dan hukum oleh orang-orang pribumi.

25 Ibid., hlm. 39.

26 Rechterlijk pardon adalah kemungkinan pembebasan seseorang dari hukuman jika ia sendiri yang memberitahukan kejahatan yang telah dilakukannya kepada yang berwajib.

27 Muhammad Yasin dan Herlambang Perdana, YLBHI, Panduan Bantuan Hukum Di Indonesia, Yayasan Obor Indonesia, Jakarta, 2014, hlm. 8. 
Setelah Indonesia merdeka, arti dari pada bantuan hukum menjadi lebih luas. Landasan yuridis bantuan hukum saat kemerdekaan tetap pada Herziene Inlandsch Reglement (HIR) pada Pasal 250 dimana pemberian bantuan hukum untuk terdakwa yang diancam hukuman mati atau hukuman seumur hidup. Pelembagaan bantuan hukum di Indonesia dimulai sejak Zeyle Maker membentuk Biro Bantuan Hukum kepada rakyat yang tidak mampu di Rechts Hogeschool (RHS) Jakarta pada tahun 1940, pengelolaannya oleh Alwi St. Osman dan Elkana Tobing. Kemudian pada tahun 1953, Ting Swan Tiong mendirikan Sin Ming Hui atau dikenal dengan Tjandra Naya, suatu organisasi sosial dari pada orang-orang Indonesia keturunan Cina, yang memberi Bantuan Hukum dalam setiap perkara kepada anggotanya. Dengan demikian mengenai Bantuan Hukum untuk anggota Tjandra Naya tidak terbatas kepada perkara yang diancam hukuman mati saja, tetapi diberikan dalam segala macam perkara, meskipun ada batasan lain, yaitu bahwa bantuan hukum hanya diberikan kepada suatu golongan keturunan Cina saja. ${ }^{28}$ Pada Tahun 1962, Ting Swan Tiong mengusulkan kepada Fakultas Hukum Universitas Indonesia untuk mendirikan Biro Konsultasi Hukum dan mendapat respon positif pada 2 Mei 1963. Pada tahun 1968 Biro Konsultasi Hukum yang sudah dibentuk di FH UI dirubah menjadi Lembaga Konsultasi Hukum, dan berubah lagi pada tahun 1974 menjadi Lembaga Konsultasi dan Bantuan Hukum (LKBH). ${ }^{29}$

Peraturan yang mengatur tentang bantuan hukum sebagai jaminan keadilan dalam melindungi hak-hak masyarakat miskin atau tidak mampu di Indonesia saat ini adalah:

1. Undang-Undang Republik Indonesia No. 16 Tahun 2011 Tentang Bantuan Hukum.

Secara garis besar UUBH mengatur tata cara pemberian bantuan hukum secara cumacuma kepada Penerima Bantuan Hukum yang didalamnya adalah orang atau kelompok orang miskin yang menghadapi masalah hukum.

Pemberi Bantuan Hukum yang telah memenuhi syarat UUBH ini berhak merekrut Advokat, paralegal, Dosen, dan mahasiswa Fakultas Hukum dalam melakukan pelayanan bantuan hukum yang meliputi nonlitigasi dan litigasi.

Setelah UUBH diundangkan, Pemerintah melalui Kemenkumham mengundangkan Permenkumham No. 3 Tahun 2013 Tentang Tata Cara Verifikasi dan Akreditasi LBH atau Orkemas yang memberikan bantuan hukum kepada orang atau kelompok orang miskin. Hal ini dibuat sebagai pelaksana ketentuan Pasal 7 ayat (4) UUBH.

Peraturan Pemerintah No. 42 Tahun 2013 merupakan turunan dari UUBH yang dibuat pemerintah guna keperluan pelaksanaan Pasal 15 ayat (5) dan Pasal 18 UUBH, PP No. 42 Tahun 2013 diundangkan pada 23 Mei 2013. Menteri sebagai penyelenggara bantuan 
hukum dalam tahun yang sama mengeluarkan Permenkumham No. 22 Tahun 2013 Tentang Peraturan Pelaksanaan PP No. 42 Tahun 2013. Permenkumham No. 22 Tahun 2013 ini diundangkan dimana pembuatannya bertujuan untuk pelaksanaan ketentuan Pasal 17, Pasal 23 ayat (4), Pasal 29 ayat (2), dan Pasal 31 ayat (3) dari PP No. 42 Tahun 2013. Hal menarik yang dibahas adalah mengenai standarisasi bantuan hukum yang didalamnya mengatur standar bantuan hukum litigasi dan nonlitigasi, standar pelaksanaan bantuan hukum, standar pemberian bantuan hukum, dan standar pelaporan pengelolaan anggaran Pemberi Bantuan Hukum.

2. Undang-Undang Republik Indonesia No. 48 Tahun 2009 Tentang Kekuasaan Kehakiman.

Bantuan hukum dalam UndangUndang Kekuasaan Kehakiman terdapat pada Bab XI dalam Pasal 56 dan 57. Pasal 56 ayat (1) menjelaskan bahwa hak dari seseorang yang tersangkut dalam suatu perkara untuk mendapatkan bantuan hukum dari Pemberi Bantuan Hukum, sesuai dengan sifat dan hakekat dari suatu negara hukum yang menempatkan supremasi hukum diatas segalanya yang berfungsi sebagai pelindung dan pengayom terhadap semua warga masyarakat disamping adanya jaminan perlindungan terhadap hak-hak asasi manusia. Selanjutnya Pasal 56 ayat (2) menjelaskan negara menanggung biaya perkara bagi pencari keadilan yang tidak mampu. Pasal 57 ayat (1) menjelaskan bahwa pada setiap pengadilan negeri dibentuk Pos Bantuan Hukum untuk pencari keadilan yang tidak mampu dalam memperoleh bantuan hukum sebagai landasannya UUBH jo. Undang-Undang No. 12 Tahun 2005 Tentang Pengesahan International Contenant On Civil And Political Rights (Konvenan Internasional Tentang Hak-hak Sipil dan Politik).

3. Undang-Undang Republik Indonesia No. 49 Tahun 2009 Tentang Peradilan Umum. Kebutuhan hukum masyarakat dari sisi bantuan hukum sangat penting untuk mencapai peradilan yang merdeka dan adil, maka dari itu Undang-Undang Peradilan Umum pada Pasal 68B yang menjelaskan bahwa bantuan hukum berhak diperoleh oleh siapa saja yang tersangkut perkara hukum, dan biaya perkara bagi pencari keadilan yang tidak mampu ditanggung oleh negara. Kemudian Pasal 68C menyebutkan pembentukan Pos Bantuan Hukum yang memberikan bantuan hukum secara cuma-cuma bagi siapa saja yang tidak mampu yang sedang tersangkut perkara hukum sampai putusannya inkrah. ${ }^{30}$

4. Undang-Undang Republik Indonesia No. 50 Tahun 2009 Tentang Perubahan Kedua Atas Undang-Undang No. 7 Tahun 1989 Tentang Peradilan Agama.

Bantuan hukum dalam Undang-Undang No. 50 Tahun 2009 Tentang Peradilan Agama termuat dalam Pasal 60B yang menjelaskan 
bahwa bantuan hukum berhak diperoleh jasa hukum yang diberikan oleh Advokat setiap orang yang tersangkut perkara hukum, bantuan hukum bagi pencari keadilan yang tidak mampu biayanya ditanggung oleh negara dengan syarat melampirkan bukti tidak mampu. Selanjutnya dalam Pasal 60C yang menjelaskan Pos Bantuan Hukum dibentuk di tiap pengadilan agama untuk pelayanan bantuan hukum pada semua tingkat peradilan bagi pencari keadilan yang tidak mampu hingga memperoleh putusan inkrah.

5. Undang-Undang Republik Indonesia No. 51 Tahun 2009 Tentang Peradilan Tata Usaha Negara.

Bantuan hukum dalam peradilan tata usaha negara termuat dalam UndangUndang No. 51 Tahun 2009 pada Pasal 57 yang menjelaskan hak untuk didampingi dan diwakili oleh kuasa. Kemudian mangacu pada Undang-Undang No. 5 Tahun 1986 Pasal 60 menjelaskan bersengketa dengan cuma-cuma dengan syarat bukti tidak mampu. Selanjutnya Pasal 61 menjelaskan kewajiban pengadilan dalam menetapkan permohonan berperkara secara cuma-cuma.

6. Undang-Undang Republik Indonesia No. 18 Tahun 2003 Tentang Advokat.

Bantuan hukum cuma-cuma dalam Undang-Undang Advokat terdapat pada Pasal 1 ayat (9) yang menjelaskan pengertian bantuan hukum. Bantuan Hukum adalah secara cuma-cuma kepada klien yang tidak mampu. Kemudian diatur pada Pasal 22 yang menjelaskan Advokat berkewajiban memberikan bantuan hukum kepada pencari keadilan yang tidak mampu.

7. Undang-Undang Republik Indonesia No. 8 Tahun 1981 Tentang Kitab UndangUndang Hukum Acara Pidana.

Bantuan hukum KUHAP diatur dalam Bab VI Pasal 54 yang menjelaskan tersangka/ terdakwa berhak mendapat bantuan hukum dari penasihat hukum untuk kepentingan pembelaan. Kemudian Pasal 56 menjelaskan tersangka atau terdakwa yang diancam pidana mati atau pidana lima belas tahun atau lebih atau bagi tidak mampu yang diancam pidana lima tahun atau lebih wajib mendapat penasihat hukum. Bantuan hukum kepada tersangka diberikan atau dapat diminta sejak dalam penangkapan atau penahanan pada semua tingkat pemeriksaan, baik pada tingkat penyidikan meupun pada tingkat pemeriksaan pengadilan. Pada pemeriksaan tingkat penyidik, maka tersangka didampingi oleh penasihat hukum, yang boleh hadir dalam pemeriksaan yang sedang berjalan, hanya bersikap pasif, artinya ia hanya mendengarkan dan melihat pemeriksaan, yang diatur dalam Pasal 69 hingga Pasal 74 dan Pasal 115 ayat (1), dan Pasal 156 KUHAP. ${ }^{31}$

\footnotetext{
31 Martiman Prodjohamidjojo, Penasihat dan Organisasi Bantuan Hukum, Ghalia Indonesia, Jakarta, 1984,
} hlm. 19. 


\section{B. Pelaksana Bantuan Hukum}

Pelaksana Bantuan Hukum dalam UUBH adalah Lembaga Bantuan Hukum atau Organisasi Kemasyarakatan selanjutnya disingkat LBH dan Orkemas. Pelaksana Bantuan Hukum dalam Undang-undang Mahkamah Agung pada Pasal 42 disebut juga sebagai pembela. Undang-undang Kekuasaan Kehakiman menyebutkan adanya pengakuan pemberian bantuan hukum sebagaimana termuat dalam ketentuan Pasal 38 ayat (2) huruf d Undang-undang Peradilan Umum dengan ketentuan Pasal 68C dimana setiap Pengadilan Negeri dibentuk Pos Bantuan Hukum. Pemberian bantuan hukum menurut UUBH dilaksanakan oleh Pelaksana Bantuan Hukum yang sudah berbadan hukum, terakreditasi, memiliki kantor atau sekretariat tetap, memiliki pengurus dan program bantuan hukum sesuai Pasal 8.

LBH sesuai yang termuat dalam Pasal 1 ayat (6) PP No. 83 Tahun 2008 Tentang Persyaratan dan Tata Cara Pemberian Bantuan Hukum Secara Cuma-Cuma diartikan sebagai lembaga yang memberikan bantuan hukum kepada pencari keadilan tanpa menerima pembayaran honorarium. Para aktivis Pemberi Bantuan Hukum memasukkan konsep bantuan hukum gender struktural sebagai respon atas ketidak adilan gender akibat relasi kuasa yang timpang antar jenis kelamin. ${ }^{32}$ Kegiatan bantuan hukum yang dikembangkan meliputi penyadaran dan pengorganisasian masyarakat, kampanye pers dan kerjasama dengan wartawan yang lain, mengusahakan pertisipasi mitra yang optimal dalam penanganan perkara hukum dan keadilan, menggali dan membuat nyata serta menganalisis kasus-kasus pelanggaran keadilan yang belum manifest, mengusahakan kerjasama dengan kekuatan yang ada dan tumbuh di masyarakat diantaranya tokoh informal baik indifidual maupun kolektif. ${ }^{33}$

Orkemas adalah organisasi berbasis kemasyarakatan yang tidak bertujuan politis. Orkemas haruslah berbadan hukum, yakni berdasarkan Staatsblad 1870 No. 64, serta Undang-undang No. 16 Tahun 2001 Tentang Yayasan sebagaimana telah diubah dengan Undang-undang No. 28 Tahun 2004 kemudian diperbaharui dalam Pasal 10 ayat (1) huruf a Undang-undang No. 17 Tahun 2013 dan dijelaskan lebih lanjut pada Pasal 11 sampai dengan Pasal 13 Undang-undang Orkemas. Menurut Pasal 1 ayat (1) Undang-undang No. 17 Tahun 2013, Orkemas didirikan dan dibentuk oleh masyarakat secara sukarela berdasarkan kesamaan aspirasi, kehendak, kebutuhan, kepentingan, kegiatan, dan tujuan untuk berpartisipasi dalam pembangunan demi tercapainya tujuan NKRI yang berdasarkan Pancasila. ${ }^{34}$

32 Kelompok Kerja Paralegal Indonesia, Kritisi Rancangan UUBH dari Aspek Paralegal dan Pemberdayaan Hukum (Legal Empowerment), KKPI, Jakarta, 2014, hlm. 15.

33 Benny K. Harman, Mulyana W. Kusumah, Hendardi, Paskah Irianto, Sigit Pranawa, dan Tedjabayu, LBH Memberdayakan Rakyat, Membangun Demokrasi, YLBHI, Jakarta, 1995, hlm. 7.

34 Wawancara dengan Hisar P. Rumapea, Bankesbang Medan, 17 Oktober 2014. 
Orang yang melaksanakan pemberian bantuan hukum p;ada kantor Pelaksana Bantuan Hukum adalah Advokat, paralegal, Dosen dan Mahasiswa FH yang memenuhi syarat. Advokat adalah orang yang berprofesi memberi jasa hukum, baik di dalam maupun di luar pengadilan yang memenuhi persyaratan berdasarkan ketentuan Undang-undang Advokat, dalam naskah ini khusus klien yang tidak mampu atau orang miskin.

Dasar pertama pemberian bantuan hukum adalah Mukadimah Anggaran Dasar PERADIN, menyatakan bahwasannya hak setiap orang untuk mendapat perlakuan dan perlindungan yang sama oleh undangundang sesuai dengan asas rule of law dalam masyarakat merdeka. ${ }^{35}$

Syarat standar pelaksana Advokat dalam memberikan bantuan hukum diantaranya Advokatharusterdaftarpadasalah satu Pemberi Bantuan Hukum yang terakreditasi, tidak sedang menjalani hukuman pemberhentian sementara waktu atas pelanggaran AD, ART atau pelanggaran peraturan internal atau kode etik profesi yang dibuktikan dengan surat keterangan dari organisasi induk Advokat.

Pemberian bantuan hukum dapat juga dilakukan oleh calon Advokat (CA), disebut juga sebagai kandidat. Kewenangan dari kandidat dalam beracara tidak dapat mandiri, kandidat terbatas dalam melakukan pembelaan di muka pengadilan dengan memerlukan pendampingan dari Advokat pendamping. Seorang kandidat dapat diberikan izin sementara praktik Advokat segera setelah diterimanaya Laporan Penerimaan Calon Advokat Magang yang memenuhi persyaratan sebagaimana diatur dalam Peraturan Perhimpunan Advokat Indonesia No. 1 Tahun 2006 dan dapat diikutsertakan dalam surat kuasa Advokat pendamping.

Paralegal adalah seseorang yang bukan pengacara atau bukan Advokat tetapi memiliki keterampilan hukum dan mendapatkan pelatihan yang dibuktikan dengan sertifikat pelatihan paralegal yang diselenggarakan oleh Pemberi Bantuan Hukum, Perguruan Tinggi, LSM yang memberika bantuan hukum, dan lembaga pemerintah yang menjalankan fungsinya dibidang hukum, sehingga dapat membantu kerja pengacara atau Advokat dalam memberikan bantuan hukum. ${ }^{36}$ Pada era dikeluarkannya UUBH, tugas seorang paralegal juga menjalankan aktivitas advokasi, pengorganisasian, pembelaan hak dan kepentingan hukum masyarakat, serta menyusun rencana tindakan hukum yang akan dilakukan dalam Advokasi.$^{37}$

Paralegal harus terdaftar pada salah satu Kantor Pelaksana Bantuan Hukum yang

35 Badan Kontak Profesi Hukum Lampung, Penegakan Hukum dalam Mensukseskan Pembangunan, Alumni, Bandung, 1977, hlm. 33. 
terakreditasi, serta wajib tunduk dan patuh terhadap kode etiknya. ${ }^{38}$ Paralegal dibutuhkan dalam kegiatan pencerahan hukum sebagai bukti rencananya akan dibuat sertifikasi dari Organisasi Advokat kepada paralegal yang lolos kualifikasi dengan syarat-syarat tertentu. ${ }^{39}$

Dosen adalah seorang yang berprofesi sebagai pendidik profesional dan ilmuwan dengan tugas utama mengajarkan, mengembangkan, dan menyebarluaskan ilmu pengetahuan yang dikuasai melalui pendidikan, jurnal, dan pengabdian kepada masyarakat dengan mulia dan tanggung jawab. Keterlibatan para Dosen FH yang terdaftar sebagai Pemberi Bantuan Hukum yang terakreditasi dan berijazah sarjana dalam program pemberian bantuan hukum mempunyai arti penting terutama eksistensinya, disamping berperan dalam pelaksanaan bantuan hukum juga Dosen umumnya mengandung aspek-aspek teoritis dalam argumentasinya sebagaimana profesi utamanya sebagai pendidik klinis di Fakultas Hukum.

Paralegal ini juga dapat berupa mahasiswa yang terlibat di dalam pemberian bantuan hukum pada Unit Bantuan Hukum. ${ }^{40}$ Mahasiswa sebagai Pemberi Bantuan Hukum harus terdaftar pada salah satu Pelaksana Bantuan Hukumyang terakreditasi, merupakan mahasiswa $\mathrm{FH}$ atau fakultas syariah yang dibuktikan dengan KTM, mahasiswa harus sudah lulus mata kuliah hukum acara pidana, hukum acara perdata, dan/atau hukum acara tata usaha negara, mahasiswa harus telah mengikuti pelatihan paralegal. ${ }^{41}$

Pelaksanaan program bantuan hukum di lapangan misalnya yang terdapat di kantor Pelaksana Bantuan Hukum dapat dilihat dari akreditasinya, contohnya seperti di Kota Medan yang terakreditasi $\mathrm{B}$ hanya LBH Medan, selebihnya terakreditasi C dimana jumlah Advokat yang tergabung hanya dua orang, ${ }^{42}$

Pemberian pelayanan bantuan hukum seharusnya hanya dapat diberikan oleh Pemberi Bantuan Hukum yang independen dan bukan PNS, pembatasan eksistensi PNS dalam pengadilan dikarenakan untuk menjaga kualitas, dimana Dosen sebagai PNS dikhawatirkan dapat terintervensi pemerintah karena PNS berada dibawah Eksekutif (Kemendikbud), ${ }^{43}$ kecuali Dosen yang bukan

38 Pasal 9 Undang-undang No. 16 Tahun 2011 tentang Bantuan Hukum jo Pasal 13 ayat (4) PP No. 42 Thn 2013 tentang Syarat dan Tata Cara Pemberian Bantuan Hukum dan Penyaluran Dana Bantuan Hukum jo. Psl 27 Permen No. 22 Thn 2013 tentang Peraturan Pelaksanaan PP No. 42 Tahun 2013 tentang Syarat dan Tata Cara Pemberian Bantuan Hukum dan Penyaluran Dana Bantuan Hukum.

39 Wawancara dengan Dartimnov M. T. Harahap, Kemenkumham Medan, 23 September 2014.

40 Wawancara dengan Muhammad Hayat, Medan, 21 November 2014.

41 Pasal 29 Permen No. 22 Tahun 2013 tentang Peraturan Pelaksanaan PP No. 42 Tahun 2013 tentang Syarat dan Tata Cara Pemberian Bantuan Hukum dan Penyaluran Dana Bantuan Hukum.

42 Dartimnov M. T. Harahap, Op.cit.

43 Wawancara dengan Harry Witjaksono, Komisi III DPR RI, Gedung Peradilan Semu FH USU, 16 Agustus 2014. 
PNS yang dapat mendapat izin untuk praktik sebagai Advokat. ${ }^{44}$ Hal ini kontradiktif atau bertentangan dengan ketentuan Pasal 9a UUBH, yang menyatakan bahwa Pemberi Bantuan Hukum berhak melakukan rekrutmen terhadap Dosen. Kedudukan dan wewenang Dosen pengaturannya belum jelas, hal ini berpengaruh terhadap pemberian bantuan hukum dimana seolah-olah dosen sebagai Pemberi Bantuan Hukum hanya sebatas pelengkap jika diperlukan terhadap perkara yang tidak dapat diselesaikan.

LBH atau Orkemas untuk dapat memberikan bantuan hukum sesuai Pasal 7 UUBH wajib lolos verifikasi dan akreditasi yang diselenggarakan Kemenkumham melalui Tim panitia khusus yang unsurnya dari kementerian, akademisi, tokoh masyarakat, dan lembaga atau organisasi pemberi layanan bantuan hukum. Tim tersebut adalah Tim 7 dimana permohonan yang masuk (lolos permohonan) sebagai Calon Pelaksana Bantuan Hukum khusus di Sumatera Utara sebanyak 37 (dikoreksi oleh BPHN dalam TIM 7 sebagai pengoreksi). ${ }^{45}$

Verifikasi adalah pemeriksaan atas kebenaran laporan dan dokumen yang diserahkan oleh LBH atau Orkemas. Sedangkan akreditasi adalah penilaian dan pengakuan terhadap $\mathrm{LBH}$ atau Orkemas yang akan memberikan bantuan hukum yang berupa klasifikasi atau penjenjangan dalam pemberian bantuan hukum. Pelaksanaan verifikasi dan akreditasi tehadap LBH dan Orkemas ini dilakukan setiap tiga tahun sekali dengan beberapa tahapan dimana tahapan tersebut dilaksanakan dengan proses selama empat bulan.

Pada awalnya Menteri Hukum dan HAM mengumumkan yang termuat dalam website resmi Kemenkumham tentang pelaksanaan verifikasi dan akreditasi. Kemudian LBH dan Orkemas dapat mengajukan permohonan sebagai Pemberi Bantuan Hukum kepada Menteri melalui BPHN secara online (elektronik) maupun secara manual (nonelektronik) dengan persyaratan. ${ }^{46}$ Apabila berkas dokumen yang diajukan belum lengkap, Panitia akan memberitahukan kepada pemohon secara tertulis mengenai kesalahan dan kekurangan dokumen pengajuan. Dokumen yang dinyatakan belum lengkap tersebut harus sudah diperbaiki dalam waktu empat belas hari kerja terhitung sejak tanggal surat pemberitahuan disampaikan. Sedangkan berkas dokumen yang diajukan telah dinyatakan lengkap, maka LBH atau Orkemas dapat menunggu konfirmasi pelaksanaan verifikasi dan akreditasi dari Panitia.

44 Wawancara dengan Sahala Siahaan, Ketua DPP KAI, Gedung Peradilan Semu FH USU, 16 Agustus 2014. 45 Dartimnov M. T. Harahap, Op.cit.

46 Psl 4 Peraturan Pemerintah No. 42 Tahun 2013 tentang Syarat dan Tata Cara Pemberian Bantuan Hukum dan Penyaluran Dana Bantuan Hukum. 
C. Faktor-faktoryang Mempengaruhi Implementasi Pemberi Bantuan Hukum

\section{Faktor yang mempengaruhi bantuan hukum pada organisasi masyarakat}

Dalam hal ini adalah para Pelaksana Bantuan Hukum yang terdiri dari Advokat, paralegal, Dosen dan mahasiswa Fakultas Hukum. Kurangnya pengakuan terhadap paralegal dalam beracara merupakan kendala yang sangat dirasakan. Hal ini karena kurangnya Advokat yang tergabung dalam Pemberi Bantuan Hukum menjadikan program pelaksanaan jadi terbatas. ${ }^{47}$

Anggaran pelaksanaan program bantuan hukum dirasa sangat kecil, dalam penyelesaian perkara oleh Orkemas terdapat kendala ketika menyelesaikan perkara di luar kota. Anggaran negara yang masih belum cair dikarenakan anggaran penyelesaian perkara bantuan hukum tahun 2013 reimburse ke tahun 2014. Negara tidak dapat membayar langsung pengajuan rencana penyelesaian perkara yang diberikan, meskipun teorinya untuk perkara litigasi bahwa disediakan uang muka sebesar dua juta kemudian pada saat inkrah dibayar 3 juta, namun pada kenyataannya belum bisa kleim. Reimburse dipengaruhi oleh sistem bantuan hukum yang kurang sesuai, lahirnya Undang-undang No. 16 Tahun 2011 belum serta merta dapat langsung dijalankan, pelaksanaannya memerlukan peraturan turunan. UUBH lahir di tahun 2011 sekitar Oktober sampai November, sedangkan peraturan pelaksana dibawahnya lahir pada 2013, hal inilah yang menjadi faktor yang berpengaruh dimana anggaran pelaksanaan yang dialokasikan untuk Bantuan Hukum seluruh wilayah Indonesia sebesar kurang lebih 42 Milyar rupiah tidak dapat terserap dengan baik. Perkara yang boleh di reimburse pada 2013 adalah perkara yang ditangani LBH atau Ormas yang pendaftarannya sejak 1 Juli 2013, sedangkan saat itu LBH atau Ormas belum mengetahui bahwa pendaftaran dapat dilakukan pada 1 Juli 2013. ${ }^{48}$

Faktor lain adalah masalah administratif berupa drafting dokumen dan surat keputusan pengadilan yang asli.

Kurang kerjasamanya antara stakeholder dalam penanganan kasus, terutama terhadap korban-korban trafikking. Mengatasi hal ini diperlukan kerjasama dengan pemerintah dalam program Pusat Pelayanan Terpadu Pemberdayaan Perempuan dan Anak (P2TP2A) yang merupakan pusat kegiatan terpadu yang didirikan Kementerian Pemberdayaan Perempuan dan Perlindungan Anak.

Kerugian dibawah upah normatif regional disebutkan dalam UUBH bahwa permasalahan hukum dengan objek sengketa dibawah satu juta rupiah tidak dapat dikategorikan dalam kriteria Penerima Bantuan Hukum 
kecuali perkara tersebut menarik perhatian umum. Kerugian dibawah satu juta rupiah yang dipermasalahkan dalam bantuan hukum diupayakan penyelesaiannya di luar pengadilan. ${ }^{49}$

\section{Faktor yang mempengaruhi bantuan hukum pada lembaga bantuan hukum}

Anggaran negara dimana dana yang diberikan dinilai terlalu kecil, misalnya anggaran yang diberikan untuk penyelesaian perkara pidana secara litigasi sampai putusannya inkrah sebesar lima juta rupiah.

Kesalahan salah satu oknum yang bekerja LBH akan dapat berpengaruh terhadap LBH itu sendiri dengan pemberian sanksi personal dan juga bagi LBH itu sendiri dengan penurunan grate oleh Kemenkumham. Adapun pengawasan yang dilakukan oleh BPHN adalah dengan mengadakan pemeriksaan langsung ke LBH secara berjangka namun kedatangannya tidak dapat di prediksi.

Pemberian bantuan hukum diberikan hanya kepada orang atau kelompok orang miskin dibuktikan dengan SKTM. Pemohon bantuan hukum yang memiliki SKTM ada yang memiliki aset tergolong bukan orang miskin, hal ini menjadi polemik bagi LBH karena harus menolak permonan bantuan hukum tersebut. Menurut Pengawas Daerah bahwa syarat untuk mendapatkan bantuan hukum adalah orang miskin yang dibuktikan dengan SKTM, apabila pemohon mengajukan permohonan bantuan hukum dengan syarat administrasi yang lengkap maka permohonan tersebut harus diterima. Apabila LBH atau Orkemas yang terdaftar sebagai Pelaksana Bantuan Hukum menolak karena diluar itu pemohon termasuk orang kaya, maka ini merupakan pelanggaran Pelaksana Bantuan Hukum dan dapat dilaporkan karena telah melawan negara, pemerintah menentukan kriteria miskin dengan bukti administrasi SKTM..$^{50}$

\section{Faktor yang mempengaruhi bantuan hukum pada kantor advokat}

Kendala yang ada adalah adanya anggapan bantuan hukum secara cuma-cuma merupakan belas kasihan, pencari keadilan yang tidak mampu merasa bahwa kasus yang ditangani oleh Advokat dipandang sebelah mata. Untuk mengatasi permasalahan ini maka di setiap kantor Advokat haruslah di pajang pengumuman tentang jam pelayanan, jenis pelayanan dan aturan lain agar klien mengerti prosedur. Advokat sebelum menangani perkara dapat memberitahukan terlebih dahulu tentang proses pemberian bantuan hukum secara cuma-cuma agar pencari keadilan yang tidak mampu ini mengerti dan memahami bahwa proses yang diberikan dapat adil dan tidak membeda-bedakan. ${ }^{51}$

\section{Marjoko, Op.cit.}

50 Wawancara dengan Muhammad Kaidir F. Harahap, Medan, 25 Agustus 2014.

51 Wawancara dengan Themis Simare-mare, Sekretaris DPD Peradi Medan, 9 Agustus 2014. 
Selain itu anggaran negara yang disediakan sangat kecil, proses litigasi dialokasikan dana lima juta per kasus, padahal lewat MA dana yang dialokasikan sebesar sepuluh juta. Hal tersebut lebih selayaknya hak dalam proses pemberian bantuan hukum. ${ }^{52}$

\section{Faktor yang mempengaruhi bantuan hukum secara umum}

Pemberi Bantuan Hukum mayoritas yang terakreditasi di Pulau Jawa, sementara rakyat miskin di Indonesia banyak tersebar di pelosok daerah. Hal ini menjadi faktor yang berpengaruh besar yang akan menyulitkan akses keadilan bagi kaum miskin di wilayah yang tidak terdapat lembaga atau organisasi Pemberi Bantuan Hukum. ${ }^{53}$

UUBH dalam Pasal 5 yang menyebutkan bahwa bantuan hukum diberikan kepada orang atau kelompok orang miskin yang tidak dapat memenuhi hak dasar secara layak dan mandiri. Lebih lanjut lagi dalam Pasal 6 ayat (3) Peraturan Pemerintah No. 42 Tahun 2013 memuat aturan permohonan bantuan hukum diajukan dengan melampirkan SKTM. Terdapat perbedaan syarat Penerima Bantuan Hukum oleh peraturan MA dengan UUBH, MA memberikan syarat dengan membuat/ melampirkan surat keterangan /pernyataan terdakwa bahwa ia merupakan orang tidak mampu, sedangkan UUBH mensyaratkan melampirkan SKTM. ${ }^{54}$
Asumsi bahwa Pemberi Bantuan Hukum tidak akan maksimal dalam memberikan pelayanan bantuan hukumnya karena merupakan tindakan sukarela, untuk menepis pandangan negatif masyarakat dibuatlah peraturan turunan mengenai standar bantuan hukum.

Pengawasan merupakan fungsi penilaian dan koreksi dari aktivitas Pemberi Bantuan Hukum untuk menjamin agar terjadi penyesuaian antara pelaksanaan kerja dengan rencananya. Pengawasan seharusnya melibatkan lembaga non-pemerintah, bukan dari bagian Kemenkumham saja. Pengawasan yang sedang dan akan dilaksanakan oleh lembaga pemerintah maupun nonpemerintah seharusnya diberitakan dalam suatu pemberitahuan seperti situs yang memberitakan secara berkala kegiatan pemberian bantuan hukum agar tidak terjadi penyembunyian atau bahkan arsip yang tidak bermanfaat.

\section{Simpulan}

Bantuan Hukum di Indonesia telah ada sejak kolonial Belanda dimana terdapat Lembaga Swapraja yang diperuntukkan untuk membela kepentingan hukum pribumi, namun lembaga yang mengurusi urusan pribumi tidak boleh lebih tinggi dari lembaga yang mengurus urusan pihak kolonial Belanda, kemudian dengan landasan yuridis bantuan 
hukum pada Herziene Inlandsch Reglement (HIR) pada Pasal 250 dimana pemberian bantuan hukum untuk terdakwa yang diancam hukuman mati atau hukuman seumur hidup maka dimulailah pembentukan LBH dengan membentuk Biro Konsultasi Hukum, Tjandra Naya, dilanjutkan pembentukan UBH di seluruh Fakultas Hukum Universitas Negeri di Indonesia.

Sebelum diundangkannya UndangUndang Bantuan Hukum, peraturan mengenai bantuan hukum diatur dalam:

a. Undang-Undang Republik Indonesia Nomor 48 Tahun 2009 Tentang Kekuasaan Kehakiman pada Bab XI dalam Pasal 56 dan 57,

b. Undang-Undang Republik Indonesia Nomor 49 Tahun 2009 Tentang Peradilan Umum pada Pasal 68B dan 68C,

c. Undang-Undang Republik Indonesia Nomor 50 Tahun 2009 Tentang Perubahan Kedua Atas Undang-Undang Nomor 7 Tahun 1989 Tentang Peradilan Agama pada Pasal 60B dan 60C,

d. Undang-Undang Republik Indonesia Nomor 51 Tahun 2009 Tentang Perubahan Kedua Atas Undang-Undang Nomor 5 Tahun 1986 Tentang Peradilan Tata Usaha Negara pada Pasal 57,

e. Undang-Undang Republik Indonesia Nomor 18 Tahun 2003 Tentang Advokat pada Pasal 1 ayat (9) dan Pasal 22,

f. Undang-Undang Republik Indonesia Nomor 8 Tahun 1981 Tentang Kitab Undang-Undang Hukum Acara Pidana pada Bab VI pada Pasal 54 dan Pasal 46.
Peraturan perundang-undangan yang mengatur mengenai bantuan hukum telah di fokuskan pada Undang-Undang Nomor 16 Tahun 2013 Tentang Bantuan Hukum beserta turunannya (PP No. 42 Tahun 2013, PERMEN No. 3 Tahun 2013, PERMEN No. 22 Tahun 2013) dimana peraturan tersebut mendukung pelaksanaan bantuan hukum untuk orang atau kelompok orang miskin, aturan tersebut menyangkut ketentuan umum, ruang lingkup, penyelenggaraan dan standar pelaksanaan, Pemberi Bantuan Hukum, hak dan kewajiban, syarat dan tata cara, pendanaan,larangan dan sanksi. Semua peraturan mengenai bantuan hukum sebelum undang-undang bantuan hukum diundangkan, masih dapat berlaku asal tidak bertentangan.

Pemberian bantuan hukum secara litigasi dapat diperoleh dengan cara pengajuan permohonan kepada Pelaksana Bantuan Hukum dengan mengisi data dan melengkapi persyaratan, permohonan yang disetujui oleh Pelaksana Bantuan Hukum dilanjutkan dengan membuat surat kuasa khusus dan pemberian bantuan hukum sudah dapat dilaksanakan.

Pemberi Bantuan Hukum terdiri dari Penyelenggara Bantuan Hukum dalam hal ini adalah Kementerian Hukum dan Hak Asasi Manusia dan Pelaksana Bantuan Hukum oleh LBH dan Orkemas dimana dalam pelaksanaan membutuhkan peran para Pemberi Bantuan Hukum yang terdiri dari Advokat, paralegal, dosen dan mahasiswa FH, instansi-instansi negara dan masyarakat. Kedudukan Pelaksana Bantuan Hukum secara 
litigasi yakni Advokat sebagai pendamping sedangkan paralegal, dosen dan mahasiswa FH juga dapat mendampingi Penerima Bantuan Hukum apabila Advokat pendamping mendapat kendala, namun pendampingan paralegal, dosen dan mahasiswa $\mathrm{FH}$ harus sesuai dengan persyaratan demi terciptanya tertib hukum dan memberikan rasa adil bagi Pemberi maupun Penerima Bantuan Hukum. Pelaksana Bantuan Hukum harus sudah diverifikasi dan terakreditasi Kemenkumham, hal ini sebagai syarat administrasi terkait pertanggungjawaban anggaran negara yang dipergunakan.

Pelaksanaan pemberian bantuan hukum yang telah diatur dalam UndangUndang No. 16 Tahun 2013 Tentang Bantuan Hukum masih terdapat beberapa faktor yang mempengaruhi, faktor-faktor yang mempengaruhi membuat masalah yang menjadi kendala dalam pemberian bantuan hukum, faktor tersebut banyak timbul dari Undang-Undang Bantuan Hukum itu sendiri. Faktor yang mempengaruhi pelaksanaan pemberian bantuan hukum tersebut adalah proses administrasi sebagai Pelaksana Bantuan Hukum yang dirasa rumit (verifikasi, akreditasi, pelaporan pertanggungjawaban sampai pada reimbursement anggaran), proses administrasi Pemohon Penerima Bantuan Hukum dimana harus menyerahkan SKTM yang sebelumnya harus memiliki KTP (terdapat instansi desa atau kelurahan yang tidak mau bekerjasama dalam pengeluaran SKTM karena bukan merupakan warganya), dan juga peraturan pelaksana yang dikeluarkan oleh pemerintah tidak sesuai.

\section{DAFTAR PUSTAKA}

\section{Buku}

Abdurrahman Riduan Syahrani, 1978, Hukum

dan Peradilan, Alumni, Bandung.

Adnan Buyung Nasution, 1981, Bantuan

Hukum di Indonesia, LP3ES Jakarta.

Asis Safioedin, 1973, Beberapa Hal tentang

Burgerlyk Wetboek, Alumni, Bandung.

Bambang Sunggono dan Aries Harianto, 2009,

Bantuan Hukum dan Hak Asasi Manusia, Mandar Maju, Bandung.

Benny K. Harman, Mulyana W. Kusumah, Hendardi, Paskah Irianto, Sigit
Pranawa, dan Tedjabayu, 1995, LBH Memberdayakan Rakyat, Membangun Demokrasi, YLBHI, Jakarta.

Frans Hendra Winarta, 2009, Pro Bono Publico: Hak Konstitusional Fakir Miskin untuk Memperoleh Bantuan Hukum, Gramedia, Jakarta. , 2000, Bantuan

Hukum: Suatu Hak Asasi Manusia Bukan Belas Kasihan, Elex Media Komputindo, Jakarta. 
Johny Ibrahim, 2005, Teori dan Metodologi

jurnal Hukum Normatif, Bayumedia Pblishing, Surabaya.

John Rawls, 2006, Teori Keadilan: A Theory

of Justice, Pustaka Pelajar, Yogyakarta.

Martiman Projohamijoyo, 2000, Kedudukan

Tersangka dan Terdakwa dalam

Pemeriksaan, Ghalia Indonesia, Jakarta.

, 1984, Penasihat

dan Organisasi Bantuan Hukum,

Ghalia Indonesia, Jakarta.

Mohammad Moslehudin, 1991, Filsafat

Hukum Islam dan Pemikiran

Orientalis: Studi Perbandingan

Sistem Hukum Islam, Tiara Wacana Yogya, Yogyakarta. , 1986, Philosophy

of Islamic Law and the Orientalists:

A Comparative Study Of Islamic

Legal System, Islamic Publications, Lahore.

Muhammad Yasin dan Herlambang Perdana,

2014, YLBHI, Panduan Bantuan

Hukum di Indonesia, Yayasan Obor Indonesia, Jakarta.

Mulyana W. Kusumah, 1991, Paralegal

dan Akses Masyarakat Terhadap

Keadilan, Yayasan Obor Indonesia YLBHI, Jakarta.

Sr. Mauro Cappelletti, Earl Johnson Jr. Dan James Gord Ley, 1976, Towards Equal Justice, A Comparative Study of Legal Aid in Modern Societies, Dobbes Ferry, New York.

\section{Makalah}

Abdurrahman, 1980, “Beberapa Aspek Tentang Bantuan Hukum di Indonesia", Fakultas Hukum Universitas Lambung Mangkurat.

Badan Kontak Profesi Hukum Lampung, 1977, Penegakan Hukum Dalam Mensukseskan Pembangunan, Alumni, Bandung.

Kelompok Kerja Paralegal Indonesia, 2014, "Working Paper: Kritisi RUNDANGUNDANG BH dari Aspek Paralegal dan Pemberdayaan Hukum (Legal Empowerment)", Pokjaparalegal, Jakarta.

Syafruddin Kalo, Arsip 16 Agustus 2014, "Suatu pemikiran Mengenai Undang-undang No. 18 Tahun 2003 tentang Advokat Masih Relevan Untuk Dipertahankan", Makalah Seminar Nasional Kajian Akademisi Tentang RUU Advokat, Medan. , Arsip 23 Oktober 2013

“Kuliah Program Pascasarjana Ilmu Hukum Fakultas Hukum Universitas Sumatera Utara".

\section{Peraturan Perundangan-undangan}

Undang-Undang Dasar Republik Indonesia Tahun 1945.

Undang-undang No. 8 Tahun 1981 tentang Kitab Undang-Undang Hukum Acara Pidana.

Undang-undang No. 16 Tahun 2011 tentang Bantuan Hukum. 
Undang-undang No. 48 Tahun 2009 tentang

Kekuasaan Kehakiman.

Undang-undang No. 49 Tahun 2009 tentang Peradilan Umum.

Undang-undang No. 50 Tahun 2009 tentang

Perubahan Kedua Atas Undangundang No. 7 Tahun 1989 tentang Peradilan Agama.

Undang-undang No. 51 Tahun 2009 tentang

Perubahan Kedua Atas Undangundang No. 5 Tahun 1986 tentang Peradilan Tata Usaha Negara.

Undang-undang No. 18 Tahun 2003 tentang Advokat.

Peraturan Pemerintah RI No. 42 Tahun 2013 tentang Syarat dan Tata Cara
Pemberian Bantuan Hukum dan Penyaluran Dana Bantuan Hukum.

Peraturan Pemerintah No. 6 Tahun 1974 tentang Pembatasan Kegiatan Pegawai Negeri dalam Usaha Swasta. Peraturan Menteri Hukum dan Hak Asasi Manusia RI No. 3 Tahun 2013 tentang Tata Cara Verifikasi dan Akreditasi LBH atau Orkemas.

Peraturan Menteri Hukum dan Hak Asasi Manusia RI No. 22 Tahun 2013 tentang Peraturan Pelaksanaan Peraturan Pemerintah RI No. 42 Tahun 2013 tentang Syarat dan Tata Cara Pemberian Bantuan Hukum dan Penyaluran Dana Bantuan Hukum.

Kitab Undang-Undang Hukum Acara Pidana. 